\title{
加速器施設における放射線管理
}

\author{
II 。理研 RI ビームファクトリーの放射線管理 ${ }^{\dagger}$ \\ 上㝨義朋 \\ 独立行政法人 理化学研究所 仁科加速器研究センター 安全業務グループ \\ 351-0198 埼玉県和光市広沢 2-1
}

\begin{abstract}
Key Words : RIKEN Nishina Center, RIBF, accelerator health physics, heavy ion, ring cyclotron, superconducting cyclotron, radiation shielding, induced radioactivity, uranium acceleration
\end{abstract}

\section{RI ビームファクトリーの概要}

現在, 理化学研究所仁科加速器研究センター ・RIビームファクトリー (RIBF) では, 図 1 に示すように重イオン線形加速器 (RILAC) と 5 台のサイクロトロン〔AVFサイクロトロ ン (AVF)，理研リングサイクロトロン (RRC), 固定周波数リングサイクロトロン (fRC), 中 間段リングサイクロトロン（IRC）, 超伝導リ ングサイクロトロン (SRC)]が稼動し, すべ てが有機的に接続された加速器コンプレックス となっている1)。それぞれの加速器の諸元を表 1 に示す。従来からあるリニアック棟, 仁科記 念棟に加え, RIBF 加速器棟, RIBF 実験棟が 最近新たに建設された。

リングサイクロトロンとは分離セクター型の サイクロトロンをいう。 $\mathrm{fRC}$ は加速周波数が固 定であるが，RILAC, AVF, RRC, IRC, SRC はすべて可変周波数である。SRC は写真 1 に 示すように世界最大のサイクロトロンであり, 超伝導の 6 セクター電磁石から構成されている。

\footnotetext{
${ }^{\dagger}$ Radiation Control for Accelerator Facility.

II. Radiation Safety and Management at RIKEN RI Beam Factory (RIBF).

Yoshitomo Uwamino: RIKEN, Nishina Center for Accelerator-Based Science, 2-1, Hirosawa, Wako-shi, Saitama Pref. 351-0198, Japan.
}

磁場と放射線の遮へいを兼ねた厚さ $80 \mathrm{~cm} の$ 鉄板を電磁石間に張っているため，全体は円筒 形の鉄の塊に見える。鉄板はメンテナンスのた めに観音開きとなっている。

RIBF ではH HらUまでのあらゆる元素を 加速可能で, 最大エネルギーは Fe までの比較 的軽い元素で $400 \mathrm{MeV} / \mathrm{u}(/ \mathrm{u}$ は核子あたりの エネルギーであることを示す)，それより重い 元素で $350 \mathrm{MeV} / \mathrm{u}$ である。Uを加速する際は, RILAC, RRC, fRC, IRC, SRCの順にカスケ ードで加速する。軽い核では $\mathrm{fRC}$ を迂回する。 重陽子では更にIRCも迂回し, AVF, RRC, $\mathrm{SRC}$ の 3 台だけを用いる。

重イオンビームをターゲットに照射すると, 核破砕反応と核分裂反応によって元のイオンよ り軽いあらゆる核種が生成される。この核種は ビームとほぼ同じ速度と方向を持って生成され るため，これを磁場とエネルギー減衰板を組み 合わせて特定の原子番号と質量数の核種（通常 は放射性）を 2 次ビームとして取り出して実験 に用いる。この RI ビーム ${ }^{2)}$ 生成装置は仁科記 念棟と RIBF 加速器棟にあり，それぞれ RIPS (RIken Projectile-fragment Separator), BigRIPS とょんでいる。2次ビームとして引き出 される粒子はわずかであるため, 加速したビー ムのほぼ100\%がここで止まる。BigRIPSは ターゲットによって広がってしまう2 2 次ビーム 


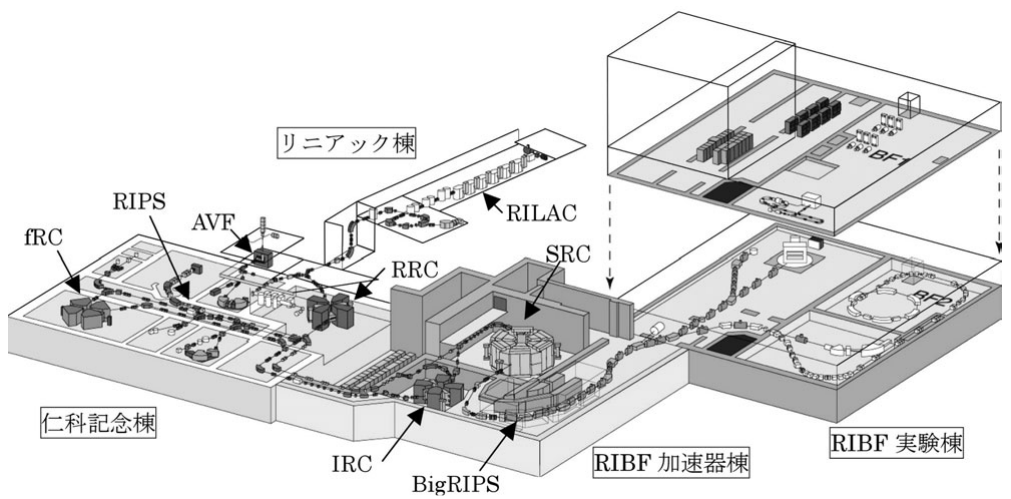

図 1 RIBF 鳥㒈図

表 1 加速器の諸元

\begin{tabular}{|c|c|c|c|}
\hline 加速器 & 加速粒子 & 最大エネルギー $(\mathrm{MeV} / \mathrm{u})$ & 最大強度 $\left(\mathrm{p} \mu \mathrm{A}^{*}\right)$ \\
\hline $\mathrm{RILAC}$ & $\mathrm{He}$ から $\mathrm{U}$ & 6 から 1.5 & 10 \\
\hline $\mathrm{AVF}$ & $\mathrm{H}$ から $\mathrm{Zr}$ & 15 から 6 & 30 から 15 \\
\hline $\mathrm{RRC}$ & $\mathrm{H}$ から $\mathrm{U}$ & 210 から 15 & 1 \\
\hline $\mathrm{fRC}$ & $\mathrm{Kr}$ から $\mathrm{U}$ & 51 (固定) & 0.1 \\
\hline $\mathrm{IRC}$ & $\mathrm{C}$ から $\mathrm{U}$ & 127 から 115 & 0.3 から 0.1 \\
\hline $\mathrm{SRC}$ & $\mathrm{C}$ から $\mathrm{U}$ & 400 から 350 & 0.3 から 0.1 \\
\hline
\end{tabular}

* 重イオンビームの強度を表す単位。「粒子（particle） micro ampere」とよぶ。加速イオンが

1 価と仮定したときの電流に相当し、 $1 \mathrm{p} \mu \mathrm{A}=6.2 \times 10^{12}$ 粒子／秒である。

なおこの強度は文部科学省から得ている許可の数值であり、現実にどのイオンでもこれに近い值 が出るわけではない。

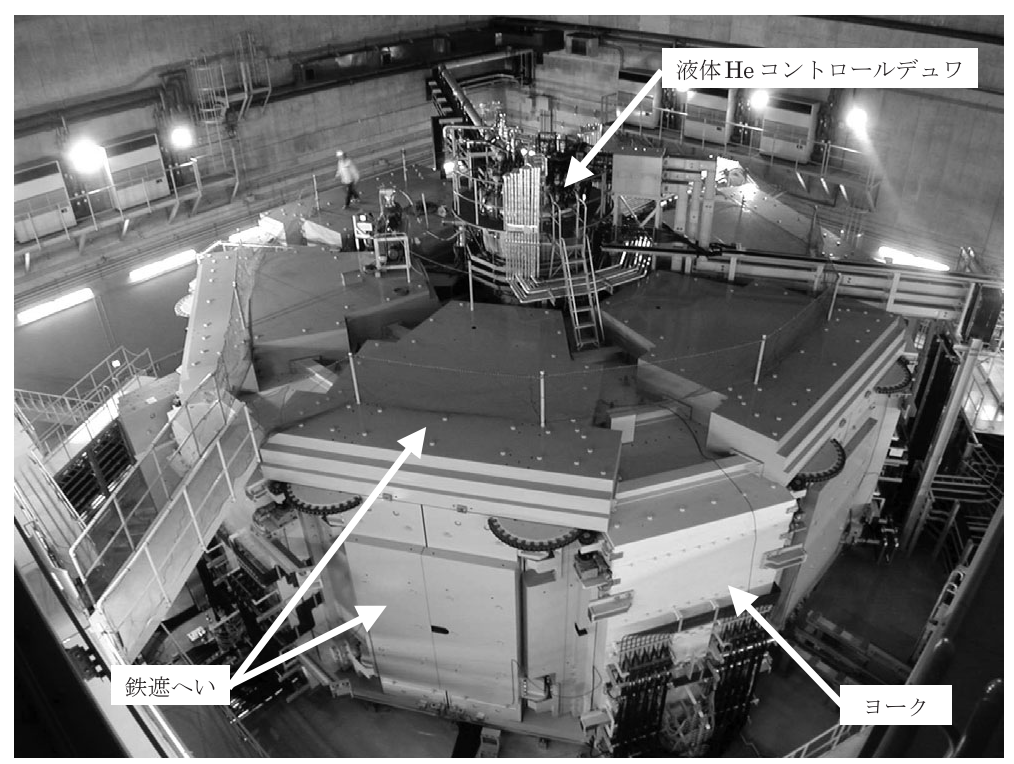

写真 1 SRC 全景。電磁石の総重量は 8100 トン 
表 2 遮へい設計の線量基準值

\begin{tabular}{|c|c|}
\hline 項目 & 設計線量基準 \\
\hline 管理区域内常時立入場所 & $1 \mathrm{mSv} /$ 週 $(25 \mu \mathrm{Sv} / \mathrm{h})$ \\
\hline 管理区域境界 & $1.3 \mathrm{mSv} / 3$ 月 $(2.6 \mu \mathrm{Sv} / \mathrm{h})$ \\
\hline 事業所境界 & $50 \mu \mathrm{Sv} / \mathrm{y}$ \\
\hline 地中外壁の表面 & $1.3 \mathrm{mSv} / \mathrm{h}$ \\
\hline
\end{tabular}

を効率よく受け入れるため, 超伝導 $\mathrm{Q}$ 電磁石 を用いて大きなアクセプタンスを持っている。

RIBF 建設の第一の目的は, 鉄より重い元素 の起源の解明や新たな原子核モデルの構築であ る。これには高い強度の RI ビーム生成が不可 欠であり, そのためには大強度の重イオンビー ムが求められ, RIBF はそれに応えるものであ る。RILACはRRCへの入射器として用いられ るとともに，世界で初めて原子番号 113 の元素 合成 ${ }^{3)}$ に成功するなど, 超重元素合成の研究な どにも単独で用いられている。AVFは単独で $\mathrm{RI}$ 生産や軽い核での不安定核ビームの生成な どにも用いられる。2007 年度からは生産した $\mathrm{RI}$ の販売を開始した。RRCでは偏極ビームや 比較的軽い不安定核ビームを用いた原子核実験 のほか，放射線育種，マルチトレーサの生成， 宇宙船搭載機器試験などの学際的研究にも利用 されている。

\section{2. 放射線遮へい}

遮へい設計 ${ }^{4}$ の目標値となる線量基準值を表 2 に示す。事業所境界の值は和光市への約束 ${ }^{\dagger}$ である。地下の建物外壁の值は, 土が放射化に よって放射性同位元素としての定義值を超えな いことと，地下水を事業所境界で飲用した場合 でも預託線量が年間 $10 \mu \mathrm{Sv}$ を超えないための 值である。他は法令のままである。

リニアック棟では 2001 年に加速エネルギー を上げた際，局所遮へいを置いて対応した。そ のため実験によっては，ビーム輸送の調整が悪

$50 \mu \mathrm{Sv} / \mathrm{y}$ は明文化されたものではなく, 従来から 大規模な加速器施設建設に先立って行われてきた 和光市への説明時に言及してきたものである。
いと想定外の場所でのビームロスの増加により 管理区域境界への漏洩線量率が $2.6 \mu \mathrm{Sv} / \mathrm{h}$ よ りも若干高くなる場合があり, 実験中の放射線 測定は重要である。線量率が高い場合はビーム 輸送の再調整や強度を下げる指示をする。ただ し許可の上限に近いビームを用いる実験はまれ であるため, 積算線量では表 2 の限度をはるか に下回る。

仁科記念棟の遮へい外壁はコンクリートで 3 $\mathrm{m}$ 以上あるため, 管理区域外への放射線漏洩 はほとんど認められない。RIPS 実験ではまれ に管理区域内の通路で $25 \mu \mathrm{Sv} / \mathrm{h}$ を超えること がある。特に ${ }^{18} \mathrm{O}$ ビームのように中性子過剩核 の場合に顕著である。その際は一部にロープを 張り，立入禁止とする

RIBF 棟では BigRIPS 周辺の遮へいが厚く, ビームダンプ上方では管理区域境界に対し全部 で $7 \mathrm{~m}$ のコンクリート遮へいがある。写真 2 はBigRIPS 本体室物品搬入口の厚さ $2 \mathrm{~m}$ の遮 へい扉である。

\section{3. 残留放射能}

運転開始から 20 年近く経過している AVF, RRCでは残留放射能による線量が高い。それ ぞれのデフレクター表面における線量率の推移 を図 2 に示す。原因となる核種は ${ }^{65} \mathrm{Zn}$ などであ る。初期はビーム強度が小さいため值は小さい が, 数年で急速に高くなった。その後もビーム 強度は上がっているが, 運転調整の上達からビ ームロスは抑えられ，線量率はほぼ一定になっ ている。

ビームエネルギーが高い RRCの方が線量率 は高いが, AVF のデフレクターは表面の比放 射能が大きく, メンテナンス時に污染を生じや すい。そのためデフレクターをフィルムで覆う などの措置をした上, 写真 3 に示す防護服を着

†法令に基づく申請では通路の滞在は週 40 時間未 満で評価している。実際の滞在時間も短時間であ るため, $25 \mu \mathrm{Sv} / \mathrm{h}$ を超えても実質的な問題はない。 立入禁止措置は注意喚起である。 


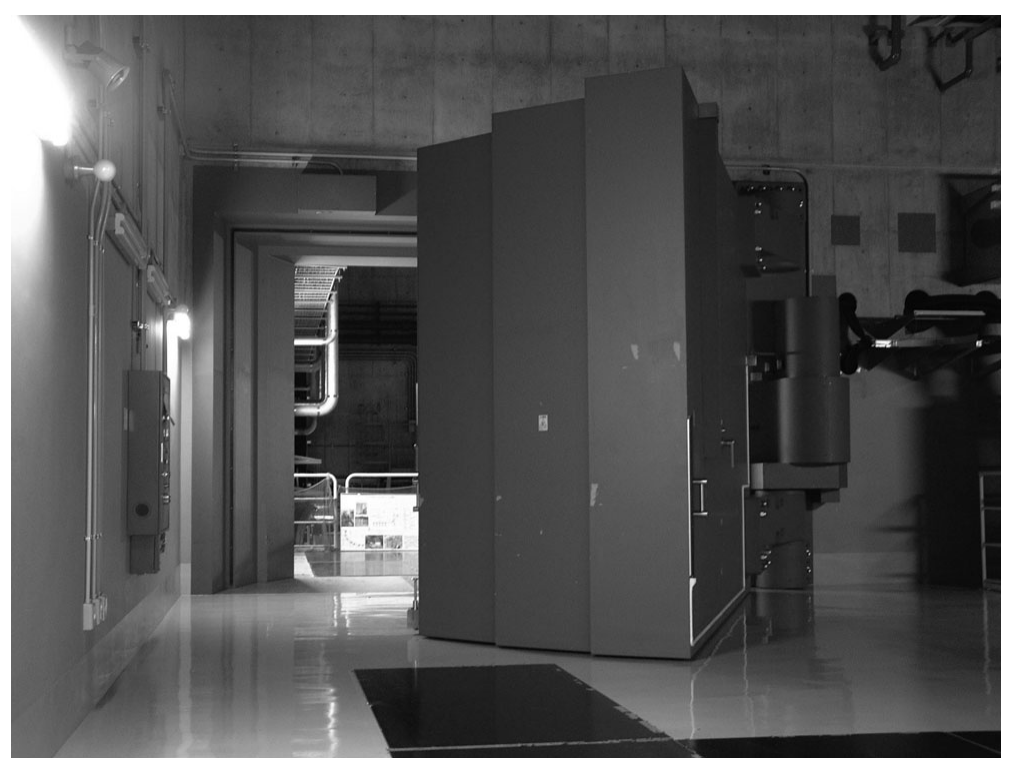

写真 2 BigRIPS 本体室遮へい扉。厚さ $2 \mathrm{~m}$ ，最小開口幅 $4 \mathrm{~m}$ のコンクリート 充填片持扉である

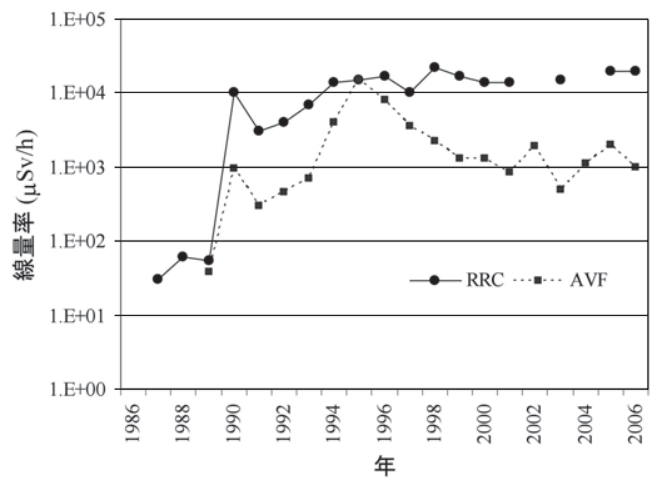

図 2 AVF とRRCのデフレクターにおける表面線 量率の推移

用し，室内污染を防ぐために空調を停止して空 気の流れを止めて作業している。

RIPSでの経験から，新しく建設した BigRIPS ではメンテナンス時の被ばくを低減する ため，比較的頻繁に行われるターゲット交換は 遠隔操作で行えるシステムを設けている（写真 4)。また電磁石は万一の交換時の被ばくを減ら すため，真空槽の接続にはピローシールを使用 するなど，比較的容易に脱着が可能な設計とな っている。

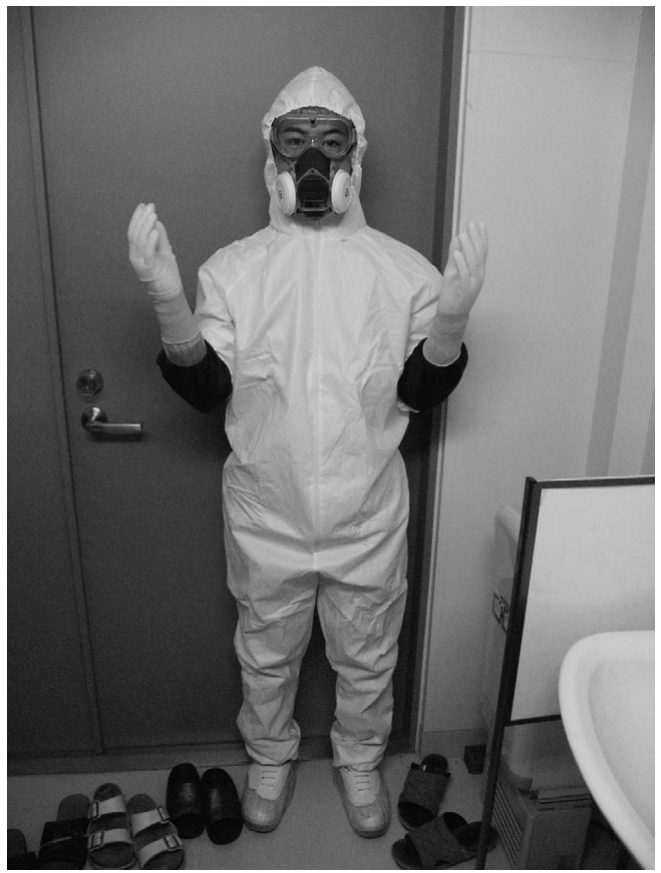

写真 3 デフレクター作業時の内部被ばく防止対策

\section{4. インタロック，放射線モニタ}

建設年代を反映し，リニアック棟のインタロ ックシステムはリレーを用いた完全なハードワ 


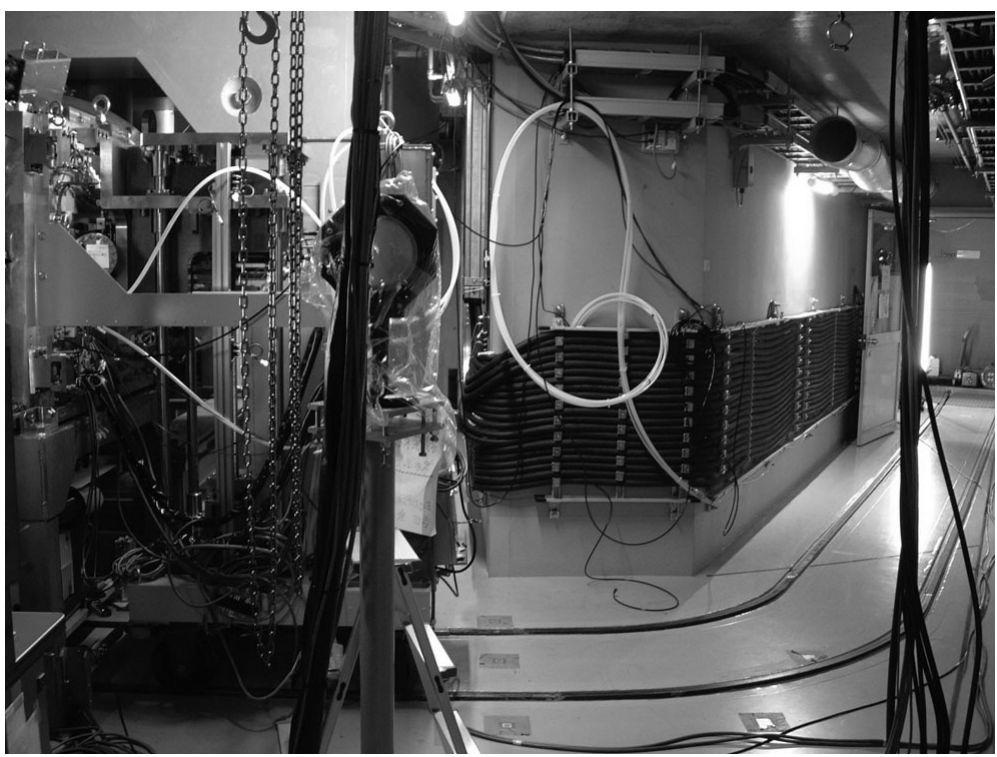

写真 4 BigRIPS ターゲット自動交換装置。左の真空チェンバーからターゲッ ト一式を取り出し, レールを進んで一時保管箱に納める

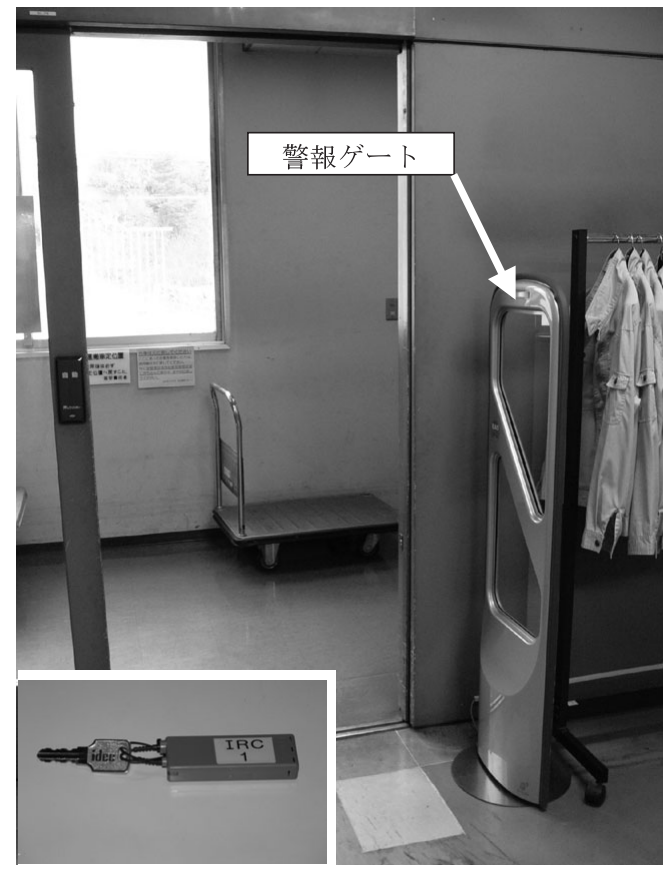

写真 5 入室安全キーに取り付けたタグ（左下）と 管理区域入口に設けた，安全キー持ち出し 防止のための警報ゲート

イヤで作られているが，仁科記念棟と RIBF 棟 は PLC (Programmable Logic Controller) で 制御している。三つの棟のシステムは完全に独
立している。

放射線モニ夕は中性子用, $\gamma$ 線用を一組とし て, 事業所境界に 4 組, リニアック棟に 3 組, 仁科記念棟に 20 組, RIBF 棟に 8 組設置して いる。仁科記念棟では照射室内にも設置してい るため台数が多いが，他は照射室周辺や管理区 域境界だけに設置している。RIBF 棟の加速器 室周辺にはビームロスをモニタするため, 比較 的安価な中性子レムカウンタを 20 台設置し, 出力をインタロック用 PLCに取り达んでいる。 $\mathrm{RIBF}$ 棟では各照射室に入退管理システムが ないため, 入室安全キーを設置した。不用意に キーが持ち帰られて運転不能になることを防ぐ ため, 写真 5 に示すようにすべてのキーに持ち 出し防止用の夕グをつけ，管理区域の入り口に 警報ゲートを設置している。これは商店で万引 防止に広く用いられているシステムである。設 置後いく度も警報が鳴っており，有効と思われ る。

\section{5. ウラン加速}

加速に用いるUの量はわずかであるが，理 研は過去の研究の経緯から「核原料物質, 核燃 
料物質及び原子炉の規制に関する法律（炬規 法)」の許可施設となっている。したがってU の加速には炉規法と「放射性同位元素等による 放射線障害の防止に関する法律 (障防法)」の両 方の規制を受ける。U 自体の危険性は炉規法の， $\mathrm{U}$ を加速することによって生じる 2 次放射線の 生成や放射化にともなう危険性は障防法の範疇 と切り分けて申請等を行っている。

$\mathrm{U}$ の取り扱いには放射能毒性よりも化学毒性 に配慮する必要がある。 ${ }^{238} \mathrm{U}$ を吸入摂取した場 合，年被ばく限度 $(20 \mathrm{mSv}$ とする）に相当す るのは $3.5 \mathrm{kBq}(0.28 \mathrm{~g})$ であるが，化学毒性 による体重 $60 \mathrm{~kg}$ の人の致死量は $0.06 \mathrm{~g}$ から $0.12 \mathrm{~g}$ とされている。

当初 ECR (Electron Cyclotron Resonance) イオン源には $\mathrm{UF}_{6}$ ガスを供給して ${ }^{238} \mathrm{U}^{14+}$ を引き 出していたが，現在では金属や酸化物などの固 体 Uを挿入して ${ }^{238} \mathrm{U}^{35+}$ を引き出している。 $\mathrm{UF}_{6}$ を用いた場合は，高温の金属との反応でイオン 源部品の表面に緑色の $\mathrm{UF}_{4}$ が析出し, 剥離し やすく污染を生じやすいという難点があった。 しかし固体 Uを用いた場合はUが強固に固着 するため取り扱いは比較的容易である。

ECR イオン源は定期的な分解清掃が必要で ある。その際には床の養生を行うなど，污染の 拡大防止策をとるとともに, 内部被ばくを防ぐ ために作業者は写真 3 に示す保護具を装着する。

従来イオン源内に付着した不純物はサンドブ ラスタ等により物理的に削り取ることにより除 去していたが，U 使用開始後は酸洗浄によって
化学的に湿式で除去している。

\section{6. おわりに}

仁科加速器研究センターでは H から U まで あらゆる元素を加速している。核子あたりのエ ネルギーが同じ場合，重イオンの方がビームパ ワーは各段に大きいため発熱の問題は厳しくな るが，飛程が小さくなるため 2 次中性子の生成 や放射化の範囲は小さい場合がある。重い核で の 2 次中性子生成は前方性が極めて強くなるな ど，加速粒子とエネルギーによって状況は大き く異なる。今後 RIBF 棟でのビーム強度が上が ってくるため, 残留放射能対策が極めて重要に なる。また放射線安全以外でも，超伝導電磁石 では $\mathrm{He}$ の漏洩による窒息の危険性がある。安 全には一時も気を抜くことができない。

\section{文献}

1) Yano, Y., Nucl. Instrum. Methods Phys. Res., B261, 1009-1013 (2007)

2）谷畑勇夫，宇宙核物理学入門，pp. 92-241, 講談 社（ブルーバックス)，東京（2002）

3) Morita, K., Morimoto, K., Kaji, D., Akiyama, T., Goto, S., Haba, H., Ideguchi, E., Kanungo, R., Katori, K., Koura, H., Kudo, H., Ohnishi, T., Ozawa, A., Suda, T., Sueki, K., Xu, H., Yamaguchi, T., Yoneda, A., Yoshida, A. and Zhao, Y.-L., J. Phys. Soc. Jpn., 73, 2593-2596 (2004)

4) Uwamino, Y., Fukunishi, N., Sakamoto, H. and Fujita, S., Safety Design of the Radioactive Isotope Beam Factory (RIBF) at RIKEN, SATIF8, Pohang (May 2006) 